\title{
Barriers to maturity in project management in the public sector: a systematic
}

\section{literature review}

\section{Barreiras à maturidade na gestão de projetos no setor público: uma revisão sistemática da}

\section{literatura}

Barreras a la madurez en la gestión de proyectos en el sector público: una revisión sistemática de la

\section{literatura}

Received: 08/09/2021 | Reviewed: 08/13/2021 | Accept: 08/15/2021 | Published: 08/17/2021

Edson Carlos da Silva Bezerra

ORCID: https://orcid.org/0000-0003-0203-3837

Universidade de Pernambuco, Brazil

E-mail: edsonsbcarlos@outlook.com

Bartira Pereira Amorim

ORCID: https://orcid.org/0000-0002-8330-4127

Universidade de Pernambuco, Brazil

E-mail: bartira.amorim@upe.br

Fagner José Coutinho de Melo

ORCID: https://orcid.org/0000-0002-0550-5177

Universidade de Pernambuco, Brazil

E-mail: fagner.melo@upe.br

\begin{abstract}
This paper aims to identify the barriers that are related to the maturity of project management in the public sector. Therefore, a systematic literature review was carried out based on works extracted from the CAPES Journal Portal and Google Scholar, using the protocol proposed by Felizardo et al. (2017) and from the keywords "project management maturity", "public-sector", "barriers" and their variations. The final review sample consisted of six studies, two of which were developed in the Brazilian context, one in the United Kingdom, one in Slovenia, one in Serbia, and one in Iceland. The barriers presented in the studies were summarized in seven dimensions: technical competence, management methodology, computerization, human relations, organizational structure, alignment with the organization's business, and transversal categories. The notes of the studies brought as main notes the needs that organizations work with the intensification of benchmarking practices in the context of project management and the integration of this area with its strategic management.
\end{abstract}

Keywords: Project management maturity; Public sector; Barriers; Systematic literature review.

\section{Resumo}

Este artigo tem como objetivo identificar as barreiras que estão relacionadas à maturidade da gestão de projetos no setor público. Para tanto, foi realizada uma revisão sistemática da literatura a partir de trabalhos extraídos do Portal de Periódicos da CAPES e do Google Scholar utilizando-se o protocolo proposto por Felizardo et al. (2017) e a partir das palavras-chave "project management maturity", "public-sector", "barriers" e suas variações. A amostra final da revisão constituiu-se de seis estudos, dos quais dois foram desenvolvidos no contexto brasileiro, um no Reino Unido, um na Eslovênia, um na Sérvia e um na Islândia. As barreiras apresentadas nos estudos foram sintetizadas em sete dimensões: competência técnica, metodologia de gestão, informatização, relações humanas, estrutura organizacional, alinhamento com os negócios da organização e categorias transversais. Os apontamentos dos estudos trouxeram como principais necessidades que as organizações trabalhem a intensificação de práticas de benchmarking no contexto da gestão de projetos e a integração desta área com a sua gestão estratégica.

Palavras-chave: Maturidade da gestão de projetos; Setor público; Barreiras; Revisão sistemática da literatura.

\section{Resumen}

Esta investigación tiene como objetivo identificar las barreras que están relacionadas con la madurez de la gestión de proyectos en el sector público. Para ello, se realizó una revisión sistemática de la literatura a partir de estudios extraídos del Portal de Revistas de la CAPES y Google Scholar utilizando el protocolo propuesto por Felizardo et al. (2017) y de las palabras clave "project management maturity", "public-sector", "barriers" y sus variaciones. La muestra final de la revisión consistió en seis estudios, dos de los cuales se desarrollaron en el contexto brasileño, uno en el Reino Unido, uno en Eslovenia, uno en Serbia y uno en Islandia. Las barreras presentadas en los estudios se 
resumieron en siete dimensiones: competencia técnica, metodología de gestión, informatización, relaciones humanas, estructura organizacional, alineamiento con el negocio de la organización y categorías transversales. En las notas de los estudios se señalaba como puntos principales las necesidades de las organizaciones que se ocupara de la intensificación de las prácticas de evaluación comparativa en el contexto de la gestión de proyectos y la integración de esta esfera con su gestión estratégica.

Palabras clave: Madurez de la gestión de proyectos; Sector público; Barreras; Revisión sistemática de la literatura.

\section{Introduction}

Given the emergence of new management concepts that seek to define the destiny of organizations and build new perspectives, there is a greater demand for innovation capacity, speed, and resilience (Kerzner, 2018). Thus, to generate profitability, the activities that generate value are increasingly important in the organizational routine and should be treated as a method rather than a process (Bezerra et al., 2018; Carvalho, 2015). Therefore, there is the search for models for monitoring the organizational activities and methodologies used that have the potential to improve the adopted practices and to optimize the progress of the processes in the short, medium, and long term. In this context, the science that studies project management practices emerge (Prado, 2010).

The project management discipline is quite old, but its application in public administration began with a focus on projects from an operational perspective. Over time, these practices have been strengthened as a means of improving the management system and more strategy-oriented perspectives have developed, defined as the strategic phase of project management or PM 5.0 (Kerzner, 2019).

Thus, the alignment between the organization and its purposes becomes a systematic structure in which all processes are structured with a focus on project success (PMBOK, 2008). For Nascimento et al. (2014), the project management methodology is the best alternative for temporary, unique, and multifunctional enterprises such as the development of innovative products, adaptation to the organizational environment and the relationship between project success and performance.

To measure these project management practices in both the public and private sectors, several Project Management Maturity Models (PMMM) have been developed. These tools enable the identification of the level of efficiency in the use of project management, thus outlining guidelines that enable performance improvement (Yazici, 2009). This level of efficiency consists of maturity, related to the ability to carry out projects, ie, the higher the efficiency and execution capacity of projects, the higher the maturity index (Prado, 2010).

The various PMMMs developed include, for example, OPM3 Model (Organizational Project Management Maturity Model), the MMGP Model (Project Management Maturity Model) developed by Darci Prado, the PMMM Model (Project Management Maturity Model) and the CMM model (Capability Maturity Model) (Nascimento et al., 2014). Thus, many authors agree that project management is a complex task, being susceptible to several barriers that make it difficult to reach high maturity stages, especially regarding the progress of projects in the public sector (Nascimento et al., 2014; Žurga, 2018; Hlodversdottir, Ingason \& Jonasson, 2013; Fraticelli, Archibald \& Prado, 2014).

However, no significant research has been found in the literature addressing these barriers to project management maturity in the public sector. In this sense, this systematic review proposes to address this subject, and considers studies on these barriers, revealing their main characteristics. Identification, description, classification, and authors who discussed them in their work will be made.

This research is guided by the following problem: How are barriers to project management maturity in the public sector being addressed in the literature? These barriers will be sought according to applied research through primary data collection. Thus, it is possible to have access to relevant information that can compose a solid and structured knowledge base 
about the defined scope, as pointed out by Felizardo et al. (2017).

The composition of this paper comprises in the next section the method adopted for the selection and analysis of relevant studies. The following are the results obtained, as well as the relevant discussions and suggestions for future research. Finally, the conclusion composes the outcome with the final opinion on the proposed objective.

\section{Methodology}

To identify the main barriers to maturity in project management in the public sector, a Systematic Literature Review (RSL) was conducted, which consists of a method that allows to aggregate evidence on a research issue to support the development of guidelines for future research (Kitchenham et al., 2009). For this, the protocol proposed by Felizardo et al was adopted. (2017), which has its step by step described below.

Figure 1: Protocol conduction flow.

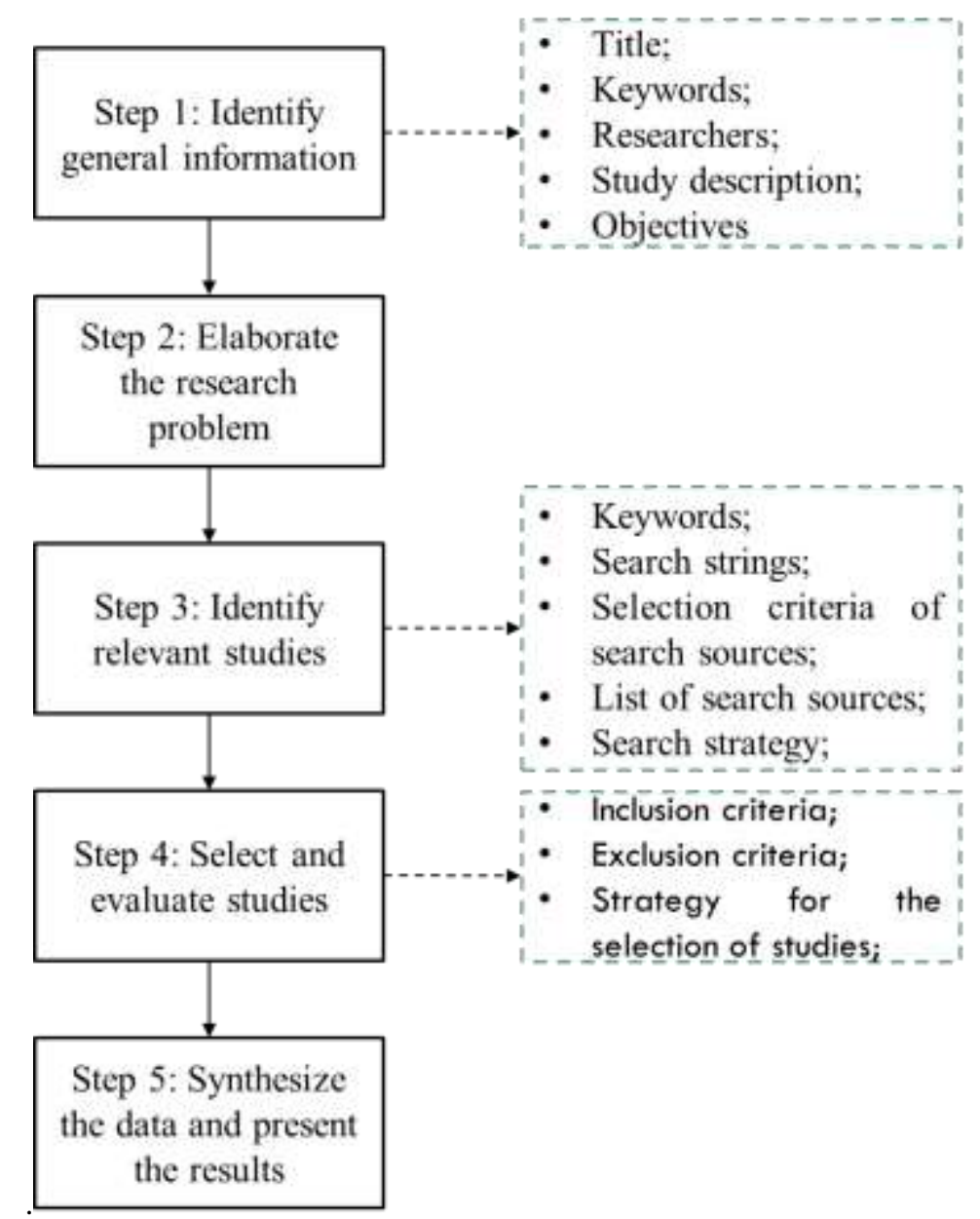

Source: Adapted from Felizardo et al. (2017).

The first and second steps of the systematic review protocol were covered in the previous sections, where they begin with the identification of general information (title, keywords, researchers, study description and objectives) and elaborate the research problem. The third step considers the identification of studies relevant to RSL, addressing the keywords, search strings, search source selection criteria, search source list, and search strategy for these sources. This information is structured in Table 1. 
Table 1: Identification of relevant studies.

\begin{tabular}{|c|c|}
\hline Keywords & $\begin{array}{l}\text { Project management maturity, public sector, barriers. Variations on these } \\
\text { keywords were also considered. }\end{array}$ \\
\hline Search Strings & $\begin{array}{l}\text { "project management maturity" AND ("public-sector" OR "public } \\
\text { administration" OR "public servic*") }\end{array}$ \\
\hline $\begin{array}{lll}\text { Search } & \text { Source } & \text { Selection } \\
\text { Criteria } & & \\
\end{array}$ & Indexing of full studies that consider the project management area. \\
\hline List of Search Sources & $\begin{array}{l}\text { Portal of journals of CAPES and Google Scholar. The choice of this } \\
\text { second source is due to the fact that, to mitigate possible problems in } \\
\text { relation to the limitations in the application of strings, a manual search } \\
\text { (Felizardo et al., 2017) was applied to this search source. }\end{array}$ \\
\hline Search Strategy & $\begin{array}{l}\text { The CAPES Journals portal applied the search string defined for this } \\
\text { search. The results were refined for articles, published between } 2009 \text { and } \\
2019 \text {, written in Portuguese or English and available in full. Because } \\
\text { studies on project management maturity, even those aimed at the public } \\
\text { sector, encompass different topics, it was decided not to define specific } \\
\text { topics. The search resulted in } 68 \text { results. In Google Scholar we used the } \\
\text { defined keywords ("Project management maturity", "public sector", } \\
\text { "barriers" and variations thereof. Thus, } 117 \text { more works were selected in } \\
\text { the sample, totaling 185). }\end{array}$ \\
\hline
\end{tabular}

Source: Authors (2020).

To identify information more accurately regarding keywords and search strings, a pilot search was performed. For Keele (2007), it consists of making an initial search within the defined research scope, collecting information essential for a more accurate understanding. Thus, studies relevant to the proposed objective are located more effectively. For the pilot search, a search was carried out on the CAPES Journal Portal with a basic search string ("project management maturity" AND "public sector"). The string was applied in English to encompass international and national studies (the latter by the abstract section).

The works read in this phase were not initially selected, given the possibility of rereading in the subsequent phases that have this purpose. Some string-matching tests were also performed in the search sources, allowing a detailed analysis of their string behavior and an appropriate refinement to the RSL.

The fourth step refers to the selection and evaluation of studies, where a more rigorous screening is performed on the sample of collected articles. At this time, the inclusion and exclusion criteria and the strategy for the selection of studies are also defined. The inclusion criteria defined were: original papers, written in English or Portuguese, published between 2009 and 2019 (the choice for this criterion is due to the fact that, according to Žurga (2018) and Kerzner (2019), this is the period which best represents the reality of project management in both the public and private sector, mainly because of methodologies such as Scrum and Agile; thus, this criterion encompasses studies with approaches to the current reality), available in full and with framing within the defined research scope. The exclusion criterion is simply not meeting all inclusion criteria.

For the study selection strategy, the 185 results from the CAPES Portal and Google Scholar were exported in digital library format (RIS) and managed by Mendeley Desktop Software. After that, it was possible to delete duplicate jobs. The remainder followed the step of reading the title, abstract and keywords and then the full reading of the articles to identify the focus of these studies and whether they address project management maturity in the public sector. In the reading phase of the title, abstract and keywords, due to Google Scholar filtering limitations, some studies have also been discarded simply because they are not scientific articles or are not written in the defined languages. Figure 2 presents the structure of these steps. 
Figure 2: Selection and evaluation of studies.

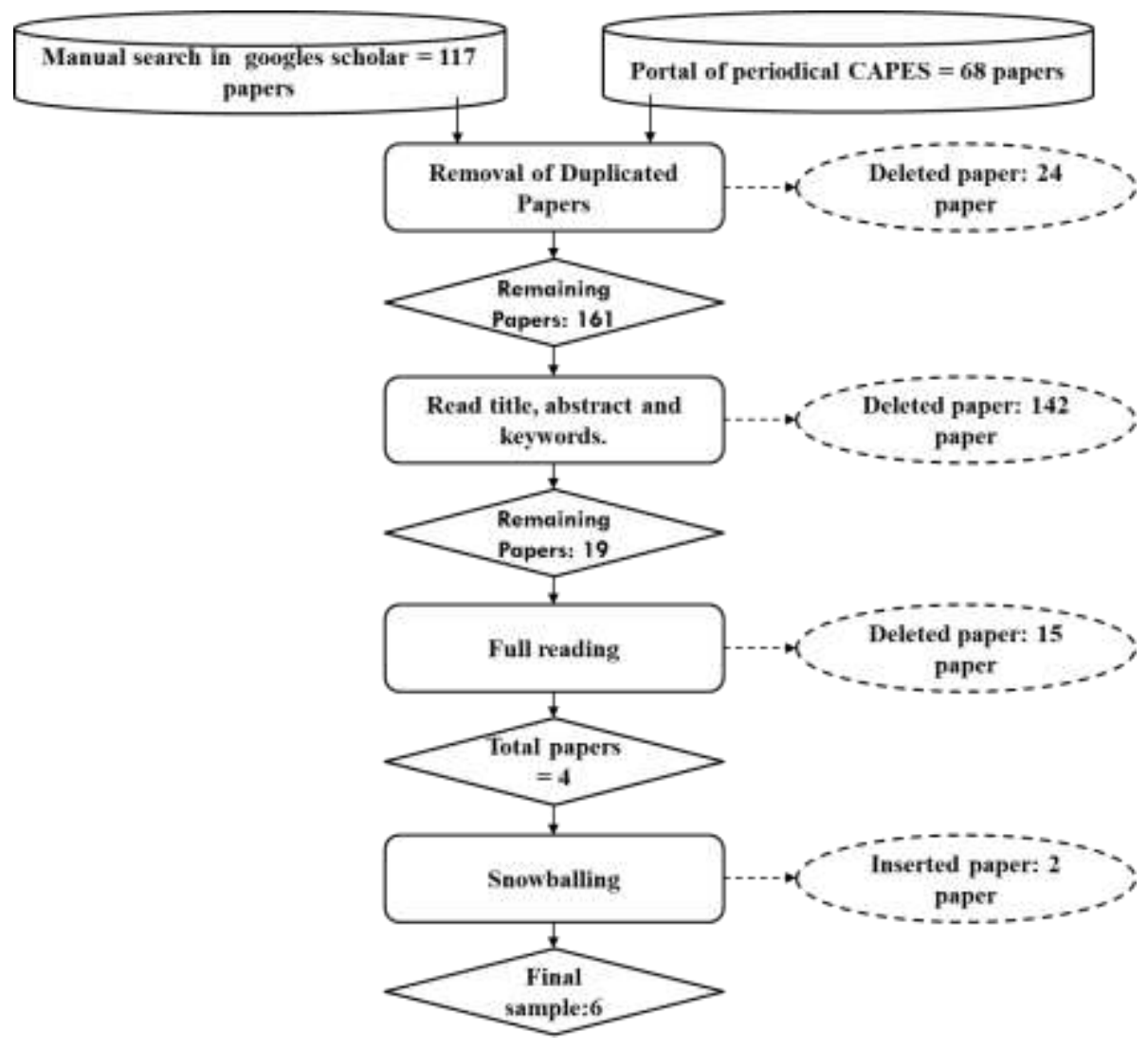

Source: Authors (2020).

After the full reading process, the snowballing method was applied. Felizardo et al. (2017) defines as a technique used to identify primary studies using the list of citations and references from studies considered relevant. Two more articles were inserted after the application of snowballing, totaling 6 papers.

The last step of the protocol by Felizardo et al. (2017) consists of synthesizing the data and presenting the results. Thus, one should clarify these two strategies. Data collection was conducted by extracting information from the full reading of the articles in a Microsoft Office Excel spreadsheet to analyze interpretation of these barriers to project management maturity in the public sector. To summarize the data, the dimensions of the Project Management Maturity Model (MMGP) of Prado (2010) were adopted: technical competence, management methodology, computerization, human relationships, organizational structure, and alignment with the organization's business. These variables are considered by Bruin et al. (2005) and Fraticelli, Archibald and Prado (2014) as the most present in the maturity models. For the different dimensions, the cross-category classification used by Barson et al. (2000) add to their studies on knowledge management, which is the relationship with more than one type of variable. Thus, the disparity between dimensions can be attenuated.

\section{Results and Discussion}

Next, the relevant results will be presented, as well as their maturity diagnostic models. The arrangement of these dimensions within the summary proposal will be clarified in this study.

\subsection{Characterization of studies and presentation of barriers}

The six studies analyzed in the final phase consist of an empirical methodology. Of these, two present a quantitative 
approach (Mihic et al., 2015; Bryde \& Leighton, 2009), three present their data from a qualitative perspective (Zurga, 2018; Birth; Veras \& Milito, 2013; Hlodversdottir; Ingason \& Jonasson, 2013) while one of them merges the qualitative and quantitative approaches (Júnior \& Feitosa, 2012).

As for where the research was applied, there is a wide variation between sectors and countries. The greater territorial proximity is composed by the two studies performed in Brazil by Nascimento, Veras and Milito (2013) and Júnior and Feitosa (2012). Further details on the studies can be identified in Table 2.

Table 2: Characterization of the studies.

\begin{tabular}{|c|c|c|c|}
\hline Authorship (year) & $\begin{array}{c}\text { Paper Title } \\
\end{array}$ & Approach & Research Direction \\
\hline $\begin{array}{l}\text { Hlodversdottir, Ingason } \\
\text { and Jonasson (2013) }\end{array}$ & $\begin{array}{l}\text { The Status of Project } \\
\text { Management within a City Hall } \\
\text { of a European Capital }\end{array}$ & Qualitative & $\begin{array}{c}\text { Department of Public Works } \\
\text { of Iceland's capital } \\
\text { Reykjavik }\end{array}$ \\
\hline $\begin{array}{l}\text { Bryde and Leighton } \\
(2009)\end{array}$ & $\begin{array}{l}\text { Improving HEI Productivity and } \\
\text { Performance through Project } \\
\text { Management }\end{array}$ & Quantitative & $\begin{array}{l}\text { United Kingdom Higher } \\
\text { Education Institutions }\end{array}$ \\
\hline Žurga (2018) & $\begin{array}{l}\text { Project Management in Public } \\
\text { Administration. TPM-Total } \\
\text { Project Management Maturity } \\
\text { Model }\end{array}$ & Qualitative & $\begin{array}{l}\text { Slovenian public } \\
\text { administration }\end{array}$ \\
\hline Mihic et al. (2015) & $\begin{array}{l}\text { Project management maturity } \\
\text { analysis in the Serbian energy } \\
\text { sector }\end{array}$ & Quantitative & Serbia Energy Sector \\
\hline Júnior and Feitosa (2012) & $\begin{array}{l}\text { Maturidade no Gerenciamento de } \\
\text { Projetos: um estudo das práticas } \\
\text { existentes nos órgãos do } \\
\text { Governo de Pernambuco }\end{array}$ & Quanti-quali & $\begin{array}{l}14 \text { secretariats of the } \\
\text { government of Pernambuco }\end{array}$ \\
\hline $\begin{array}{l}\text { Nascimento, Veras and } \\
\text { Milito (2013) }\end{array}$ & $\begin{array}{l}\text { Maturidade em projetos } \\
\text { públicos: Um estudo de caso do } \\
\text { dimensionamento de seu } \\
\text { gerenciamento }\end{array}$ & Qualitative & $\begin{array}{l}\text { State secretariats of a } \\
\text { Brazilian federative unit }\end{array}$ \\
\hline
\end{tabular}

Source: Authors (2020).

Selected literature brings major barriers to project management maturity in the public sector, making detailed analysis and comparison feasible. The structuring of these barriers resulted in Table 3 below.

Table 3: Structuring barriers between dimensions.

\begin{tabular}{|c|l|l|}
\hline \multicolumn{2}{|c|}{ DIMENSION TECHNICAL COMPETENCE } \\
\hline $\mathbf{N}^{\mathbf{0}}$ & \multicolumn{1}{|c|}{ BARRIERS } & \multicolumn{1}{c|}{ AUTHOR } \\
\hline 1 & Project management training and other areas & $\begin{array}{l}\text { Nascimento, Veras and Milito } \\
(2013) .\end{array}$ \\
\hline 2 & Inadequate technical preparation for the job & $\begin{array}{l}\text { Nascimento, Veras and Milito } \\
(2013) ; \text { Júnior and Feitosa (2012); } \\
\text { Zurga (2018). }\end{array}$ \\
\hline 3 & Project management knowledge & $\begin{array}{l}\text { Nascimento, Veras and Milito } \\
(2013) ; \text { Hlodversdottir, Ingason and } \\
\text { Jonasson (2013). }\end{array}$ \\
\hline 4 & Project Management Support & $\begin{array}{l}\text { Hlodversdottir, Ingason } \\
\text { Jonasson (2013). }\end{array}$ \\
\hline $\mathbf{N}^{\mathbf{0}}$ & \multicolumn{1}{|c|}{ and } \\
\hline 5 & Structuring a project management methodology & $\begin{array}{l}\text { AnTHOR } \\
\text { (2013); Júnior and Feitosa } \\
\text { Zurga (2018). }\end{array}$ \\
\hline
\end{tabular}




\begin{tabular}{|c|c|c|}
\hline 6 & Implementation of project management practices & $\begin{array}{l}\text { Nascimento, Veras and Milito } \\
(2013)\end{array}$ \\
\hline 7 & Few meetings & $\begin{array}{l}\text { Júnior and Feitosa (2012); Zurga } \\
\text { (2018). }\end{array}$ \\
\hline 8 & Little or no form of member evaluation & Júnior and Feitosa (2012). \\
\hline 9 & Schedule Analysis & Mihic et al. (2015). \\
\hline 10 & Work Breakdown Structure Diagrams - EAP & Mihic et al. (2015). \\
\hline 11 & Vacant processes & $\begin{array}{l}\text { Hlodversdottir, Ingason and } \\
\text { Jonasson (2013). }\end{array}$ \\
\hline \multicolumn{3}{|c|}{ DIMENSION COMPUTER } \\
\hline $\mathbf{N}^{\mathbf{0}}$ & BARRIERS & AUTHOR \\
\hline 12 & Little use or absence of information systems & $\begin{array}{l}\text { Bryde, Leighton (2009); Júnior and } \\
\text { Feitosa (2012). }\end{array}$ \\
\hline 13 & No use of a control instrument & Júnior and Feitosa (2012). \\
\hline 14 & Process Monitoring System & Mihic et al. (2015). \\
\hline 15 & IT support & Mihic et al. (2015). \\
\hline 16 & Using project management software tools & $\begin{array}{l}\text { Mihic et al. (2015); Hlodversdottir, } \\
\text { Ingason and Jonasson (2013). }\end{array}$ \\
\hline 17 & Information Management & $\begin{array}{lll}\text { Hlodversdottir, Ingason } & \text { and } \\
\text { Jonasson (2013). } & \end{array}$ \\
\hline \multicolumn{3}{|c|}{ DIMENSION HUMAN RELATIONSHIPS } \\
\hline $\mathbf{N}^{\mathbf{0}}$ & BARRIERS & AUTHOR \\
\hline 18 & People management issues & $\begin{array}{l}\text { Nascimento, Veras and Milito } \\
\text { (2013). }\end{array}$ \\
\hline 19 & Relationship between departments & Júnior and Feitosa (2012). \\
\hline 20 & Communication efficiency & Mihic et al. (2015). \\
\hline \multicolumn{3}{|c|}{$\begin{array}{l}\text { DIMENSION ORGANIZATIONAL STRUCTURE } \\
\end{array}$} \\
\hline $\mathbf{N}^{\mathbf{0}}$ & BARRIERS & AUTHOR \\
\hline 21 & Project Management Office & $\begin{array}{l}\text { Bryde and Leighton (2009); Zurga } \\
\text { (2018). }\end{array}$ \\
\hline 22 & Leadership recognized by the team & Bryde and Leighton (2009) \\
\hline 23 & Senior management & $\begin{array}{lrr}\text { Bryde and Leighton } & \text { (2009); } \\
\text { Hlodversdottir, } & \text { Ingason } & \text { and } \\
\text { Jonasson (2013). } & & \\
\end{array}$ \\
\hline 24 & Coordination between different sectors & $\begin{array}{l}\text { Nascimento, Veras and Milito } \\
(2013) .\end{array}$ \\
\hline 26 & Establishment of routines & $\begin{array}{l}\text { Júnior and Feitosa } \\
\text { Nascimento, Veras and } \\
\text { (2013). }\end{array}$ \\
\hline 27 & Delivery delays & Júnior and Feitosa (2012). \\
\hline 28 & Delegation of duties & $\begin{array}{lll}\text { Hlodversdottir, } & \text { Ingason } & \text { and } \\
\text { Jonasson (2013). } & & \\
\end{array}$ \\
\hline \multicolumn{3}{|c|}{ DIMENSION STRATEGIC ALIGNMENT } \\
\hline $\mathbf{N}^{\mathbf{0}}$ & BARRIERS & AUTHOR \\
\hline 29 & $\begin{array}{l}\text { Poor integration between Project management and strategic } \\
\text { management }\end{array}$ & Zurga (2018). \\
\hline 30 & Risk management & Mihic et al. (2015). \\
\hline 31 & Strategic management & Mihic et al. (2015). \\
\hline \multicolumn{3}{|c|}{ CROSS CATEGORIES } \\
\hline $\mathbf{N}^{\mathbf{0}}$ & BARRIERS & AUTHOR \\
\hline 32 & Lack of project-related infrastructure & Bryde and Leighton (2009). \\
\hline 33 & $\begin{array}{l}\text { Impaired ability of higher education institutions to manage } \\
\text { change }\end{array}$ & Bryde and Leighton (2009). \\
\hline 34 & Poor ability to sustain business activities & Bryde and Leighton (2009). \\
\hline 35 & Initial efforts are underway around project management & $\begin{array}{l}\text { Nascimento, Veras and Milito } \\
(2013) .\end{array}$ \\
\hline 36 & Actions under development are distributed differently & $\begin{array}{l}\text { Nascimento, Veras and Milito } \\
(2013) \text {. }\end{array}$ \\
\hline 37 & Assembly of project teams & Júnior and Feitosa (2012). \\
\hline
\end{tabular}




\begin{tabular}{|c|l|l|}
\hline 38 & Sudden changes of priorities & Júnior and Feitosa (2012). \\
\hline 39 & Influence of political issues & Zurga (2018). \\
\hline 40 & External Audits & Mihic et al. (2015). \\
\hline 41 & A lot of time is used & $\begin{array}{l}\text { Hlodversdottir, Ingason and } \\
\text { Jonasson (2013). }\end{array}$ \\
\hline 42 & Too often projects are not completed & $\begin{array}{l}\text { Hlodversdottir, Ingason and } \\
\text { Jonasson (2013). }\end{array}$ \\
\hline 43 & Tracking and updating is inappropriate & $\begin{array}{l}\text { Hlodversdottir, Ingason and } \\
\text { Jonasson (2013). }\end{array}$ \\
\hline 44 & Investment & $\begin{array}{l}\text { Hlodversdottir, Ingason and } \\
\text { Jonasson (2013); Mihic et al. } \\
(2015) .\end{array}$ \\
\hline
\end{tabular}

Source: Authors (2020).

The following sections discuss each category in detail and present discussions on barriers to the maturity of project management in the public sector, its limitations, and suggestions for future research.

\subsection{Dimension Technical Competence}

The low project management maturity rate found by Nascimento, Veras and Milito (2013) in the Public Security Secretariat of a Brazilian federative unit reflects the lack of training in project management and other areas, causing problems in structuring an effective methodology. management Coupled with this, managers care little about their project management skills, while neglecting the skills of other employees. Nascimento, Veras and Milito (2013) and Junior and Feitosa (2012) state that lack of training is one of the biggest problems affecting the Brazilian reality in the public sector, both in relation to project management and in other areas.

Similarly, Hlodversdottir, Ingason and Jonasson (2013) and Zurga (2018) also identified problems regarding the training of public administration officials in Iceland and Slovenia, respectively. The Public Works Department of the Icelandic capital has an Operations Manual and an Information Security Manual, however, employees state that these manuals are not being used properly due to the lack of training in different areas, including management of projects. Moreover, these authors state that although the overall maturity rate of Reikjavik city is considered high, there is still a lack of support in project management, precisely due to the lack of training of managers in this area. In the case of Slovenian public administration, the lack of training causes problems of alignment between strategy and project management.

\subsection{Dimension Management Methodology}

One of the most discussed barriers is related to the difficulty of recognizing a clear methodology that involves project management (Zurga, 2018; Birth; Veras \& Milito, 2013; Júnior \& Feitosa, 2012). According to Nascimento, Veras and Milito (2013), the low maturity index found in the study indicated that, in general, the public administration studied did not make consistent efforts to implement any project management practice, as initial efforts are problematic. Respondents in the studies by Júnior and Feitosa (2012) and Zurga (2018) stated that, in general, in the project management of Pernambuco and Slovenian public agencies, there is no easily identifiable management methodology that uses the concepts of phases or life cycle of a project. In Slovenia, although there are efforts for a common project management methodology, it was adopted in 1997 and is considered outdated.

Two studies (Zurga, 2018; Júnior \& Feitosa, 2012) identified problems regarding meetings between members of the public administration. They reported that their project management is based on informal meetings, where team members are asked about the progress of tasks. Members of Pernambuco's public agencies in the research by Júnior and Feitosa (2012) also argue about the absence of an adequate form of member evaluation. According to them, only the achievement of goals is 
evaluated, but in a shallow way and without defined criteria.

In another aspect, Mihic et al. (2015) identified problems regarding the use of project planning methods and techniques (schedule analysis, work breakdown structure diagrams, critical events, etc.). The maturity assessment in these strands was found to be quite low, causing several coordination problems between project activities.

Still regarding the management methodology, the study by Hlodversdottir, Ingason and Jonasson (2013) reported that the project management processes are very vague, with no depth of goal setting and some activities considered critical are treated as routine and not received. due attention from managers and employees.

\subsection{Dimension Computer}

Regarding the computerization of the processes that help in project management, Bryde, Leighton (2009) and Junior and Feitosa (2012) identified, respectively, in the state government of Pernambuco and in the United Kingdom Higher Education Institutions. Use of available information systems, providing clear evidence of the immature status of computerization. Junior and Feitosa (2012) and Mihic et al. (2015) also reported the lack of a process control aid tool, using only informal control methodologies. In addition to the lack of these support systems, Mihic et al. (2015) also reported that in sectors where management information systems are present, there is a lack of IT (Information Technology) support so that employees can be more familiar with the use of these systems.

Turning to technological support focused exclusively on effective project management practices, Mihic et al. (2015) and Hlodversdottir, Ingason, Jonasson (2013) did not find clear evidence of the presence of project management software. Thus, project management maturity has been compromised and has led the management of Serbia and Iceland to face problems in completing their projects.

\subsection{Dimension Human Relationships}

This dimension was, in general, one of the best evaluated among the analyzed studies. Bryde and Leighton (2009), Zurga (2018) and Hlodversdottir, Ingason and Jonasson (2013) reported the presence of satisfactory indices in relation to the relationships between the members of the units studied. However, Nascimento, Veras and Milito (2013) identified serious problems in the management of human resources throughout the national territory, jeopardizing project success and compromising the efficiency of the government.

Similarly, Junior and Feitosa (2012) argue that the Pernambuco government agencies have deficiencies in communication between different departments. Respondents reported that there is some individuality in the processes and there are no efforts to unify the sectors and act more integrated. These authors argue that one of the causes pointed out was the lack of use of a control instrument and the lack of structuring of an efficient project management methodology (presented in the previous sections).

On the other hand, Mihic et al. (2015) reported problems in communication between members of the same department. They noted that the measurement of communication efficiency is underdeveloped, thereby impeding efforts focused on benchmarking and implementing measures to improve this aspect of project maturity.

\subsection{Dimension Organizational Structure}

All the authors reported in their studies the presence of barriers regarding the organizational structure, which is one of the biggest problems affecting the public sector regarding project management (Zurga, 2018).

Bryde and Leighton (2009) identified three barriers regarding organizational structure. The first refers to the same barrier that was also reported by Zurga (2018) in Slovenia: the lack of a project management office to meet the demands of 
different sectors in carrying out their projects, resulting in lower evaluation scores. of maturity. The second is the difficulty in recognizing employees' leading leadership, as the delegation of duties and follow-up activities are not well structured. The third bears a strong resemblance to the second but turns to the lack of a leader with knowledge in project management, also identified in the research by Hlodversdottir, Ingason and Jonasson (2013). While on the one hand UK higher education institutions lack a project management office, on the other hand, along with the public works department of the capital of Iceland, they also need professionals able to lead in the light of management practices. of projects (Hlodversdottir; Ingason \& Jonasson, 2013; Bryde \& Leighton, 2009).

The data collected by Nascimento, Veras and Milito (2013) showed that the sectors of the studied public agencies have intense difficulty in coordinating an integration between sectors. In Junior and Feitosa's study this problem was related to human relationships; However, in this case, Nascimento, Veras and Milito (2013) identified that the lack of coordination between different sectors was caused by a management structure that did not favor external relations, thus, the project management maturity of these sectors was compromised.

Hlodversdottir, Ingason and Jonasson (2013) also identified problems in delegation of duties. Because there is a shortage of qualified professionals, the ability to delegate roles appropriate to the skills of each employee is compromised. Many projects are smaller short-term projects with unclear leaders, and it is often unclear who should do what.

The two surveys conducted in Brazil (Nascimento; Veras \& Milito, 2013; Júnior \& Feitosa, 2012) reported that there are no established routines and that employees follow a very variable schedule, which makes it difficult to assimilate several factors essential to adaptation in the sector. public. Júnior and Feitosa (2012) state that instability in the objectives is much more frequent than in the private sector, which can represent large productivity losses. On the other hand, Nascimento, Veras and Milito (2013) point out that the lack of routines also causes the barrier related to frequent delays in delivery, making the process even more problematic.

\subsection{Dimension Strategic Alignment}

Only two studies presented barriers regarding the strategic alignment of the organization, that is, the commitment to organizational objectives. The study by Nascimento, Veras and Milito (2013) presented only the project management maturity index (level 2 - considered a stage of creation and consolidation of a common project management language), but did not detail these results. Research by Bryde and Leighton (2009), Junior and Feitosa (2012), and Hlodversdottir, Ingason and Jonasson (2013) did not consider this dimension.

However, Mihic et al. (2015) identified issues related to both risk management and strategic management. Risk management is how the organization deals with key variables to project success, so management in this case needs a tight integration between organizational strategy and project management (Mihic et al., 2015). The authors report that statistically relevant dependencies between project duration, stakeholder management, inconsistencies between the need for strategic management in organizations and the implementation of their procedures led to low levels of maturity in this dimension.

Similarly, Zurga (2018) identified in Slovenia the lack of integration between strategy and project management. According to the author, there are rules and legal bases for integration and processes are formalized, but the area is not yet managed properly, which compromises this integration in the medium and long term.

\subsection{Cross Categories}

Barson et al. (2000) define this dimension as the union of characteristics between distinct dimensions. In terms of project management, some barriers have characteristics and causes that relate to more than one-dimension MMGP of Prado (2010). Thus, the inclusion of cross-categories facilitates the analysis of barriers and promotes further reflection. 
Thus, Bryde and Leighton (2009) identified three cross-category barriers. The first is the lack of project-related infrastructure, ie the lack of effective efforts to improve project management practices, mainly due to the lack of a project management office, inefficient use of information systems. and poor coordination between different sectors of the UK Higher Education Institutions. The second is the inefficiency of change management as a result of the intense changes that UK HEIs are undergoing as competition and new technologies increase. And the third barrier identified refers to the poor ability to sustain business activities, as the absence of a project management office and more effective communication is leading to continual shifts in focus and effort.

Nascimento, Veras and Milito (2013) found that, despite efforts to find a project management methodology, factors such as poorly valued routines and problems around human resource management are making this transition even longer. Moreover, the development actions are distributed differently, since while the Infrastructure Secretariat is concerned with structuring a project management base, the Administration and Human Resources Secretariat is not concerned with undertaking this work perspective in this way learning and establishing important routines.

In this same vein, Junior and Feitosa (2012) identified problems in the assembly of project teams. According to the interviewees, there is not much freedom to compose the project team according to technical criteria. People usually already make up the staff, and sometimes the staff is supplemented by people appointed by politicians who do not have the profile the job requires. Sudden changes in priorities were also noted by the authors, mainly caused by the lack of a defined management structure and the definition of project management practices.

Similarly, Zurga (2018) identified the influence of political issues on Slovenian management. The author states that the basis for including projects in the portfolio is political will, where most projects were included in coalition agreements and the inclusion of projects added later had political consent.

Mihic et al. (2015) found that one of the biggest project management problems in the Serbian energy sector is the rise in external audits, as only 33\% of operations are monitored. The authors argue that problems with project quality in Serbia's state-owned energy sector could be solved by the implementation and certification of the ISO-9000 quality management system.

Hlodversdottir, Ingason and Jonasson (2013) reported three project-related barriers: excessive project time, projects that are not often completed, and inadequate follow-up and updating. These authors argue that these problems occur because of the need to monitor operations by a project manager, as the team is well qualified and project management is being used to some extent.

In addition, Hlodversdottir, Ingason and Jonasson (2013) and Mihic et al. (2015) report that all processes could be better executed if the government had more investments, which would bring more qualification and tools to support proper project management.

Thus, it was possible to observe that all studies presented barriers framed in the cross categories. However, there is only one common barrier between more than one study analyzed in this dimension, which is the lack of investments, which reveals the great peculiarities that the public sector has in relation to project management.

The structuring of these barriers provides an analysis of what the selected literature presented in project management in the public sector. However, as this area of knowledge is still quite scarce in public administration, especially regarding the diagnosis of project management maturity (Mihic et al., 2015; Hlodversdottir; Ingason \& Jonasson, 2013; Birth; Veras \& Milito, 2013; Júnior \& Feitosa, 2012; Bryde \& Leighton, 2009), it is necessary to analyze in the next section the suggestions for future research of the 6 studies analyzed. 


\section{Conclusion}

Through this systematic literature review, it was possible to analyze which barriers hinder maturity in project management in the public sector. After the searches, within the inclusion and exclusivity criteria established, 6 studies relevant to the defined objective could be extracted in different locations ( 2 in Brazil, 1 in Serbia, 1 in the United Kingdom, 1 in Slovenia and 1 in Iceland) and application sectors.

The results of these studies point to many barriers that must be fought so that high maturity rates in project management can be achieved. Forty-four barriers were identified, arranged in 4 related to technical competence, 7 to management methodology, 6 to computerization, 3 to human relationships, 8 to structure, 3 to strategic alignment and 13 to cross-categories. This analysis also allowed identifying the limitations of studies that were related to the inability to generalize the results, because only a few sectors were analyzed and the sample quantitatively low in some studies.

From the studies analyzed some suggestions for future research can be presented: 1) development of research in the context of Higher Education Institutions, providing more theoretical and practical resources that favor benchmarking of project management and comparison with different sectors of public and private power; 2) verification of the influence of managers' characteristics on the maturity of project management, outline ing guidelines for solving problems that undermine organizational projects; 3 ) analysis of the effect of integration between strategic management and project management within public organizations and the scientific development of methodologies and tools to support these activities; and 4) the evaluation of project management maturity in municipal governments.

Thus, it is possible to affirm that this review provides a deeper reflection on the challenges of public administration in the search for better project management indexes and opens space for the need to include more studies of this nature both in the public and private sectors, or both, for comparative research purposes.

\section{References}

Barson, R. J., Foster, G., Struck, T., Ratchev, S., Pawar, K., Weber, F., \& Wunram, M. (2000). Inter-and intra-organisational barriers to sharing knowledge in the extended supply-chain. Proceedings of the eBusiness and eWork.

Bezerra, M. C. C., Lima, R. T. D., Maciel, M. M. F., \& Silva, R. M. (2018). Framework para determinação das barreiras à gestão do conhecimento. Revista Produção Online. 18(4), 1398-1421.

Bruin, T., Freeze, R. D., Ulkarni, U., \& Rosemann, M. (2005) Understanding the main phases of developing a maturity assessment model. In: 16th Australian Conference on Information Systems, Sydney. ACIS 2005 Proceedings.

Bryde, D., \& Leighton, D. (2009). Improving HEI Productivity and Performance through Project Management. Educational Management Administration \& Leadership, 37(5), 705-721.

Carvalho, K. E. M. (2015). Impactos do PMO no desempenho da organização pública: o caso de uma instituição de ensino superior. Revista de Gestão $e$ Projetos. 6(2), 71-84.

Felizardo, K. R., Nakagawa, E. Y., Fabbri, S. C. P. F., \& Ferrari, F. C. (2017). Revisão sistemática da literatura em engenharia de software: teoria e prática. ( $1^{\mathrm{a}}$ ed.), Elservier.

Fraticelli, A., Archibald, R., \& Prado, D. (2014). Maturity in Project Management: The Italian Experience. PM World Journal, 3(11), 1-19.

Hlodversdottir, K. H., Ingason, H. T., \& Jonasson, H. I. (2013). The Status of Project Management within a City Hall of a European Capital. Procedia - Social and Behavioral Sciences, 74, 305-315.

Júnior, A. S. S., \& Feitosa, M. G. G. (2012). Maturidade no Gerenciamento de Projetos: um estudo das práticas existentes nos órgãos do Governo de Pernambuco. Revista de Gestão e Projetos, 3(2), 207-234.

Keele, S. (2007). Diretrizes para realizar revisões sistemáticas da literatura em engenharia de software (Vol. 5). Relatório técnico, ver. 2.3 Relatório Técnico EBSE. EBSE.

Kerzner, H. (2018). The Future of Project Management. Revista de Gestão e Projetos. 9(3), 151-166.

Kerzner, H. (2019). Using the Project Management Maturity Model: Strategic Planning for Project Management. (3a ed), John Wiley \& Sons. 
Research, Society and Development, v. 10, n. 10, e513101019223, 2021

(CC BY 4.0) | ISSN 2525-3409 | DOI: http://dx.doi.org/10.33448/rsd-v10i10.19223

Kitchenham, B., Brereton, O. P., \& Budgen, D., Turner, M., Bailey, J., \& Linkman, S. (2009). Systematic literature reviews in software engineering-a systematic literature review. Information and software technology, 51(1), 7-15.

Mihic, M., Petrovich, D., Obradovic, V., \& Vuckovic, A. (2015). Project management maturity analysis in the Serbian energy sector. Energies, 8(5), 39243943.

Nascimento, T. C., Neto, M. V., Milito, C. M., \& Oliveira Júnior, P. C. M. (2014). Fatores que contribuem para a maturidade em gerenciamento de projetos- o caso de um governo estadual. Revista de Administração, 49(2), 415-428.

Nascimento, T. C., Veras, M., \& Milito, C. M. (2013). Maturidade em projetos públicos: Um estudo de caso do dimensionamento de seu gerenciamento. Sistemas \& Gestão, 8(3), 276-288.

PMBOK®, GUIA (Project Management Body of Knowledge). (2008). Um guia do conhecimento em gerenciamento de projetos. (4a ed.), Project Management Institute, Four Campus Boulevard, Newtown Square, PA 19073-3299 EUA.

Prado, D. S. (2010). Maturidade em gerenciamento de projetos. (2a ed.), INDG Tecnologia e Serviços Ltda.

Yazici, H. J. (2009). The role of project management maturity and organizational culture in perceived performance. Sage Journals, 40(3), 14-33.

Žurga, G. (2018). Project Management in Public Administration. TPM-Total Project Management Maturity Model. The Case of Slovenian Public Administration. Transylvanian Review of Administrative Sciences, 14(53), 144-159. 